71 卷 706 号 (2005-6)

\title{
エタノール混合燃料を活用したディーゼル機関の排気改善*
}

\author{
Ali MOHAMMADI*1, 石山拓二*1, 奇 成 笅*1 \\ 堀部 直 ${ }^{* 2}$, 角田貴 章*3

\section{Improvement in Exhaust Emissions from a Diesel Engine Utilizing Ethanol Blended Fuel} \\ Ali MOHAMMADI*4, Takuji ISHIYAMA, Sung-Sub KEE, \\ Naoto HORIBE and Takaaki KAKUTA \\ ${ }^{* 4}$ Graduate School of Energy Science, Kyoto University, \\ Yoshida Honmachi, Sakyo ku, Kyoto-shi, Kyoto, 606-8501 Japan

\begin{abstract}
Effects of ethanol blending on performance and emissions of a direct injection diesel engine equipped with common rail injection and cold EGR systems were investigated under various ethanol blending conditions. The results indicate that ethanol blending with high injection pressure offers smoke-free combustion under high engine loading. However, this gives an increase in combustion noise and $\mathrm{NO}_{x}$ emissions. In such a condition, employing pilot injection and cold-EGR lowers the combustion noise and greatly improves the $\mathrm{NO}_{x}-\mathrm{PM}$ trade-off. Under low engine loading, usage of pilot injection with proper timing and amount improves combustion stability and lowers emissions of unburned species. The overall results indicate that maximum acceptable ethanol blending does not exceed $20 \%$.
\end{abstract}

Key Words: Internal Combustion Engine, Diesel Engine, Fuel Injection, Ethanol Blend

\section{1.はじめに}

エタノールは含酸素然料であるため,ディーゼル

機関で用いることによって高いすす抑制効果が期待 できる(1)(2). したがって, 有用な代替然料の一つとし て早くから注目され，エンジンにおける利用法につ いて研究が行われてきた. エタノールはセタン価が 非常に低いため, 着火性を確保することが主眼とさ れ, グロープラグや点火プラグによる着火, 補助燃 料の噴射，および怪油との混合による利用などの燃 烧技術が検討されてきた.

最近では，バイオマス然料の一つとして， $\mathrm{CO}_{2}$ 抑制 の镜点からエタノールが再び注目されるようになり， 取り扱いの安全性, 製造コスト, ならびに排気改善 効果など幅広く研究が行われている(3)(4). 最近の研究 においては，機関の改造が最小にできることから， 怪油との混合による利用が主に取り扱われ，怪油そ の他の然料との相溶性や, 相溶剂, セタン価向上剂 の効果などについても検討されている(5 10).

* 原稿受付 2004 等 11 月 1 日

*1 正員, 尔都大学エネルギー科学研究科( 606-8501 京都市 左京区吕田本町).

*2 日産自動車(株)（-2300053 横活节鶴見区大黑町）。

*3 宗都大学、ネルギー科兴研究科。

E mail : ali (a energy.kyoto u.ac.jp
排気改善効果に関するこれまでの研究によると， NOx に及ぼす効果については確定的ではないが， $15 \%$ 程度の混合で $40 \%$ の粒子状物質 PM の低減が得ら れることが報告されている(4). 一方, セタン価が低下 するため, 高負荷時には燃焼騒音の増加が, 低負荷 時には不完全燃焼による未燃排気物質排出量の增加 と熱効率の悪化が報告されている(6). しかしながら， これらの研究は従来型の然焼制御技術を含んだディ 一ゼル機関で行われた研究が多く, 高圧噴射や排気 再循環（EGR）などの最新技術を採用したディーゼ ル機関での研究は少ない. 最近の電子制御噴射系の 柔軟な制御性を活用すれば，前述のようなエタノー ル混合による性能・排気の悪化を抑制できる可能性 がある.

そこで, 本研究では, パイロット噴射が可能な高 圧然料噴射装置および Cold-EGR を採用したディーゼ ル機関においてエタノール混合燃料が機関性能, 排 気特性に与える影䇾を実験的に調査したのち，高負 荷における騒音増大の抑制と NOx-PM トレードオフ の改善効果, ならびに低負荷における性能・排気の 改善を目的として, 主として噴射条件の最適化の方 策を明らかにする.

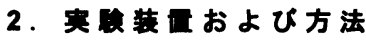

試験に使用した供試機関は，コモンレール式然料 


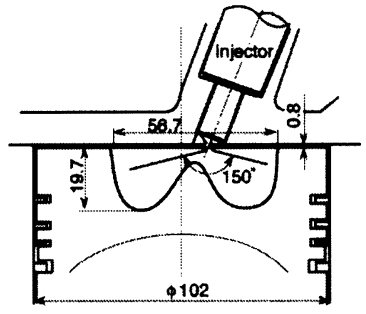

\begin{tabular}{l|l}
\hline \hline Engine type & $\begin{array}{l}\text { Direct-injection diesel engine, } \\
\text { Single cylinder, Water-conled }\end{array}$ \\
Bore $\times$ Stroke & $102 \mathrm{~mm} \times 105 \mathrm{~mm}$ \\
Displacement & $0.857 \ell$ \\
Compression ratio & $17.8: 1$ \\
Swirl ratio & 2.6 \\
Combustion & Toroidal type \\
chamber & (Chamb. dia. 56.7mm) \\
\hline
\end{tabular}

Fig. 1 Engine specification

噴射装置（デンソー製 ECD-U2P）を備えた水冷無過 給単気筒直接噴射式ディーゼル機関（口径 $102 \mathrm{~mm}$, 行程 $105 \mathrm{~mm}$ ) である. その主要諸元を図 1 に示す. 然料噴射ノズルは噴孔径 $0.18 \mathrm{~mm}$ の六噴孔のものを使 用した。然料には JIS2 号軽油（真発熱量 $45.8 \mathrm{MJ} / \mathrm{kg}$, セタン指数 57), ならびに, 軽油とエタノール（真発 熱量 $27.7 \mathrm{MJ} / \mathrm{kg}$ ）を体樌比 $85 ： 15 ， 80: 20$ および $75: 25$ で混合した燃料を使用した。 また，混合燃料 に対して分離防止のため添加郕としてオクタノール を体積比で $2 \%$ 添加した ${ }^{(11)}$. 混合然料の真発熱量は, エタノール混合割合 15，20，25\%に対して，それぞ れ怪油より $5.8 ， 6.9$ ，ならびに $8.8 \%$ 减少する. 本研 究では, EGR 率を変更したときの吸気温度の変化を 避けるため, Cold-EGR を採用した. すなわち, 高温 の排気ガスを水椧式クーラーで泠却して常温とした 後, 混合タンク内で吸入新気と混合し, 機関に吸入 させた. EGR 率は排気および吸気中の $\mathrm{CO}_{2}$ 瀑度の計 測值から総吸気量に対する再循環ガスのモル比とし て計算した，試験機関は主噴射開始時期を TDC に固 定して, 冷却水入口温度 $80^{\circ} \mathrm{C}$ 一定のもと, 回転速度 $1800 \mathrm{rpm}$ で運転した．主噴射開始時期（TDC）は，高 負荷運転時の然料消費量, NOx および PM の排出量 を熟考の上決定した.

黒煙, 窒素酸化物 NOx, 全炭化水素 THC, 一酸化 炭素 $\mathrm{CO}$ の浱度は，それぞれ Bosch 式スモークメータ， CLD 分析計（ヤナコ製, ECL30), 加熱 FID 分析計 (ヤナコ製，KA-300), FIA 分析計（ヤナコ製 ALTAS-121）を用いて計測した。粒子状物質 PM は小 型希釈トンネルを用いて採取し(12)，ソーク法を用い て固形炭素分 SOLID と可溶有機成分 SOF に分離して 秤量した。 また，排気中に含まれる低級炭化水素，

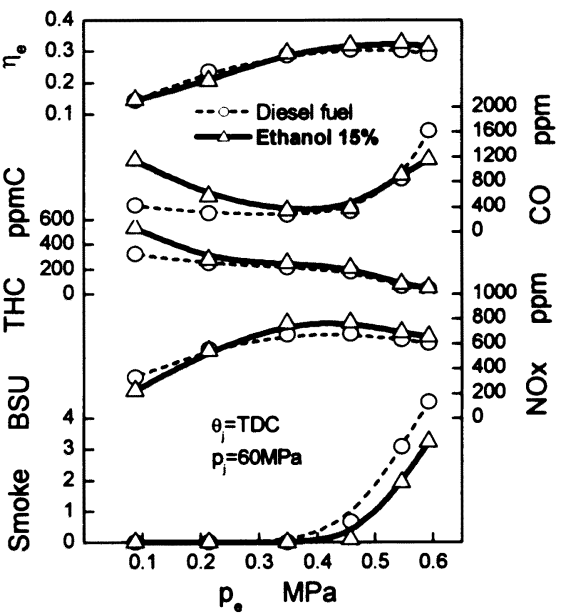

Fig. 2 Effects of ethanol blending on engine performance under various engine loads

アルデヒド類など微量成分の測定には, FTIR 分析計 （堀場製作所製 MEXA-4000FT）を使用した。

然焼解析のため，筒内圧力および然料噴射弁リフ 卜を, 圧電式圧力変換器（KISTLER 6052A）ならび に Hall 効果型センサを用いて計測した。

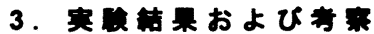

\section{1 エタノールの混合による機的性能への影}

初めに，エタノールの混合による基本的な性能・ 排気の変化を把握するため, 負荷を変化させながら 運転を行い，蛏油運転の結果と比較した．図 2 に比 較的低い噴射圧力 $\left(p_{\mathrm{j}}=60 \mathrm{MPa}\right)$ のもとで, エタノー ル $15 \%$ の混合然料を使用したときの正味平均有効圧 力 $p_{\mathrm{e}}$ に対する正味熱効率 $\eta_{\mathrm{e}}$ および排出物澌浱度を㹩 油運転と比較して示す.さらに，図 3 に, このとき の最大熱発生率 $\mathrm{d} q / \mathrm{d} \theta_{\max }$, 最大圧力上昇率 $\mathrm{d} p / \mathrm{d} \theta_{\text {max }}$, ならびに着火おくれ $\theta_{5}$ を示す。ここで，着火遅れ $\theta_{5}$ は噴射開始から，熟発生量が総発生熟量の $5 \%$ に達す るまでの期間とした.

図 2 によると,これまでにも報告されているよう に，エタノールの混合によって中負荷から高負荷に かけて黒煙 Smoke の低減がみられる。これは, エ夕 ノール自身の黒煙抑制効果だけではなく，図 3 に示 すように着火遅れが長く予混合燃焼の割合が増加し たことも原因と考えられる。また，どの負荷におい ても $\eta_{\mathrm{e}}$ に違いは見られない。 NOx は中負荷において わずかに增加するが，高負荷でエタノール混合によ るセタン価低下に起因して $\mathrm{d} p / \mathrm{d} \theta_{\max }$ が大きく増加し， 低負荷域において CO，THCなどの未然成分が増加す ることが問題である. 


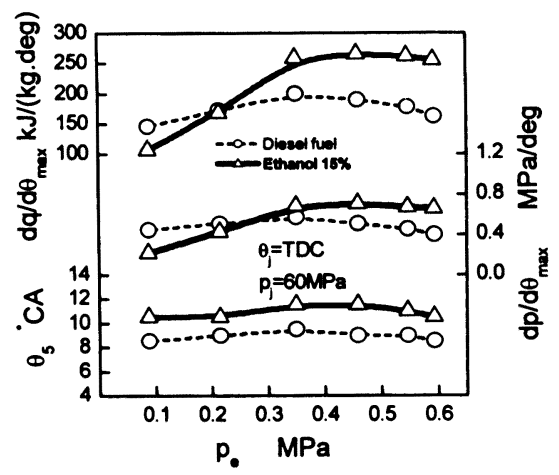

Fig. 3 Effects of ethanol blending on combustion characteristics against engine load

そこで次に，奄子制御然料噴射系の良好な制御性 を利用して，上記の問題点を解消することを試みた。 その際，高負荷ならびに低負荷それぞれについて性 能・排気の改善方法を検討するとともに，エタノー ル混合事の影警も併せて調査した.

\section{$3 \cdot 2$ 高负荷における性能・排気の改善}

3.2.1 驺射圧力の影最近のディーゼル機関は, PM 排出量を低減する目的で, 高負荷において高い噴 射圧力を用いている，そこでまず，噴射圧力の変化 がエタノール混合の効果に与える影整について調べ た.図 4 は, エタノール混合割合を $15 \%$ とし， $p_{\mathrm{e}}=0.6 \mathrm{MPa}$ の条件のもとで, 噴射圧力 $p_{\mathrm{j}}$ が熱効率 $\eta_{\mathrm{e}}$, 最大圧力上昇辛 $\mathrm{d} p / \mathrm{d} \theta_{\text {max }}$ および排出物犋洤度に及ぼす 影䇾を示す．いずれの然料でも $p_{\mathrm{j}}$ の上昇にしたがっ

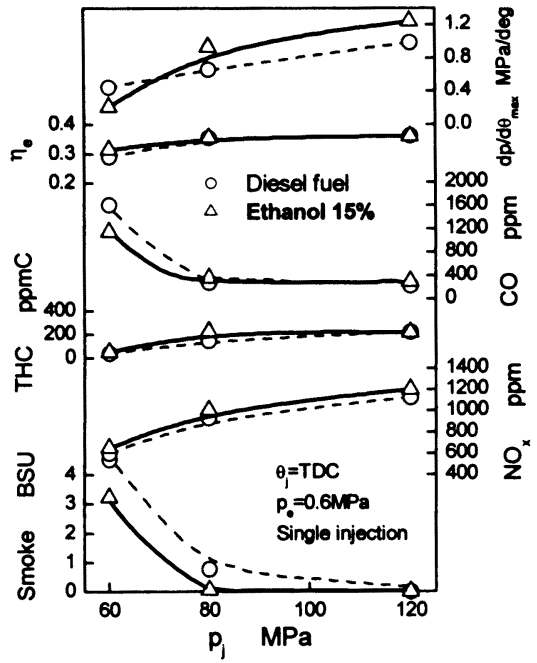

Fig. 4 Effects of injection pressure on engine performance and emissions
て，黒煙 Smoke が低减するとともに両者の差が小さ くなり, $p_{\mathrm{j}}=120 \mathrm{MPa}$ では同等となる. このように, 高 い噴射圧力では，過浱混合気の形成が防がれ，通常 の怪油でもほほ無煙燃焼となるため，エタノール混 合による黒煙低減効果は得られない。 $\mathrm{d} p / \mathrm{d} \theta_{\max }$ および NOx はどちらの然料においても， $p_{\mathrm{j}}$ が高くなるにつ れて増加する. 特に $p_{\mathrm{j}}=120 \mathrm{MPa}$ ではエタノール混合 然料，軽油どちらにおいても過大になるので対策が 必要である. なお, $\mathrm{d} p / \mathrm{d} \theta_{\text {max }}$ は高い噴射圧力の条件で もエタノールの混合によって增加する.

$3 \cdot 2 \cdot 2$ パイロット喷射の道用 PM の低減を目的 に高い噴射圧力を利用する場合には，通常の軽油を 使用する場合でも燃焼騷音が過大となる．したがっ て，最近のディーゼル機関の多くは，高負荷域にお いてパイロット噴射を行い，主然料の着火を短縮す ることで圧力上昇率を抑えている．そこで，本研究 ではエタノール混合然料にパイロット噴射を最適化 し，圧力上昇率を怪油と同等にすることを目指した。

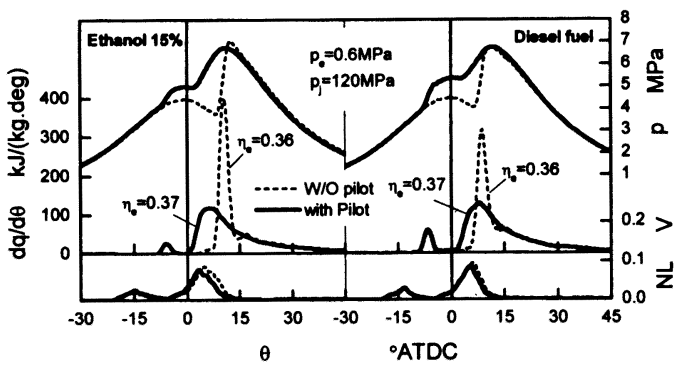

Fig. 5 Improvement in combustion process by pilot injection

図 5 はエタノールを $15 \%$ 混合した燃料について, $p_{\mathrm{e}}=0.6 \mathrm{MPa}, p_{\mathrm{j}}=120 \mathrm{MPa}$ の条件のもとでパイロット噴 射を行ったときの筒内圧力 $p$, 熱発生率 $\mathrm{d} q / \mathrm{d} \theta$ および ニードルリフトセンサ出力 NL の変化を軽油と比較し て示す.ここで、パイロット噴射量および時期はそ れぞれ $Q_{\mathrm{p}}=2 \mathrm{~mm}^{3} / \mathrm{st}, \theta_{\mathrm{p}}=15^{\circ} \mathrm{BTDC}$ である. いずれの 然料でも，パイロット噴射によって着火遅れが短縮 され，主燃料の熱発生率が低下する．エタノール混 合然料については真発熱量の低下もあってパイロッ 卜然料の発生熱量がやや低いが，主燃料の熱発生率 経過は軽油の場合とほぼ同等になる。

図 6 は $p_{\mathrm{e}}=0.6 \mathrm{MPa}, p_{\mathrm{j}}=120 \mathrm{MPa}$ の条件のもとでパイ ロット噴射量を $Q_{\mathrm{p}}=2 \mathrm{~mm}^{3} / \mathrm{st}$ に固定し, 着火遅れ $\theta_{5}$ （主噴射からの期間）, $\mathrm{d} p / \mathrm{d} \theta_{\text {max }}$ および排気穠度に及 ぼすパイロット噴射時期 $\theta_{\mathrm{p}}$ の影響を示す．パイロッ 


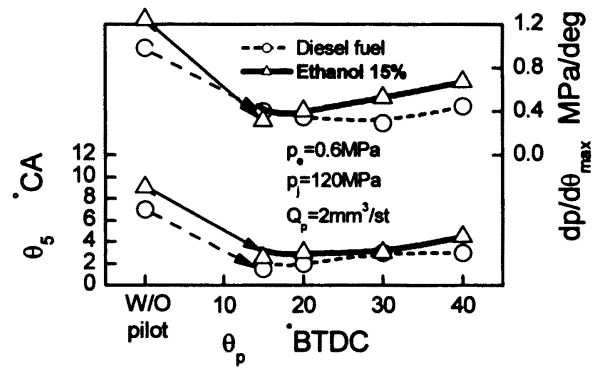

Fig. 6 Effects of pilot injection timing on combustion and emissions

卜噴射量については予備実跧の結果から，黒煙濼度 の増加を抑えるため極力少量とするのがよいことが 分かっており, 調量の精度も勘案して $Q_{\mathrm{p}}=2 \mathrm{~mm}^{3} / \mathrm{st}$ と した. 図より，いずれの燃料でも，パイロット噴射 によって $\theta_{5}$ が短縮し, $\mathrm{d} p / \mathrm{d} \theta_{\max }$ が減少する. 怪油にお いては， $\theta_{\mathrm{p}}$ を $30^{\circ} \mathrm{BTDC}$ 付近まで進角しても， $\mathrm{d} p / \mathrm{d} \theta_{\text {max }}$ を低く抑えることができるが，エタノール混 合燃料の場合は, $\mathrm{d} p / \mathrm{d} \theta_{\max }$ を怪油と同等のレベルにす るためは, 比較的遅い $15^{\circ} \mathrm{BTDC}$ に選ぶ必要がある. $\theta_{\mathrm{p}}$ を早めると, パイロット燃料の発生熱量が低下し, 主然料の熱発生率が上昇するのが見られた.エタノ 一ルの混合により, パイロット燃料の着火遅れが長 くなり, 希薄化した一部の混合気が熱発生にあずか らないことが原因と見られる.

3·2·3 エタノール混合割合の影䈏 パイロット噴 射の適用によって過大な圧力上年率を防ぐことがで きたが, その反面, 黒煙濃度が增加傾向にあった. そこで, エタノール混合割合の増加による黒煙低減 の効果を調べた，そのために，前節で求めたパイロ ット噴射条件のもとでエタノール混合割合を 20 およ び 25\%まで增加させた実験を試みた.しかし, 混合 割合を $25 \%$ としたところ, 然焼変動が激しく, 出力 を一定に維持することが困難であった．これは，噴 射量の変動によるもので, エタノールの混合による 沸点の低下に起因して, 噴射系内にボイドが生じた 可能性がある.したがって，以下の結果においては, 混合割合を $20 \%$ に制限した.

図 7 はエタノール混合割合を変更したときの简内 圧力 $p$, 熱発生率 $\mathrm{d} q / \mathrm{d} \theta$ およびニードルリフトセンサ 出力 NL をクランク角 $\theta$ に対して示す. 混合割合を增 すとともにパイロット燃料の着火遅れが長くなり, 発生熱量が减少する.これにより上死点付近での $p$ が下がるとともに, 主燃料の熱発生開始時期が遅れ, 最大筒内圧力が若干減少する.

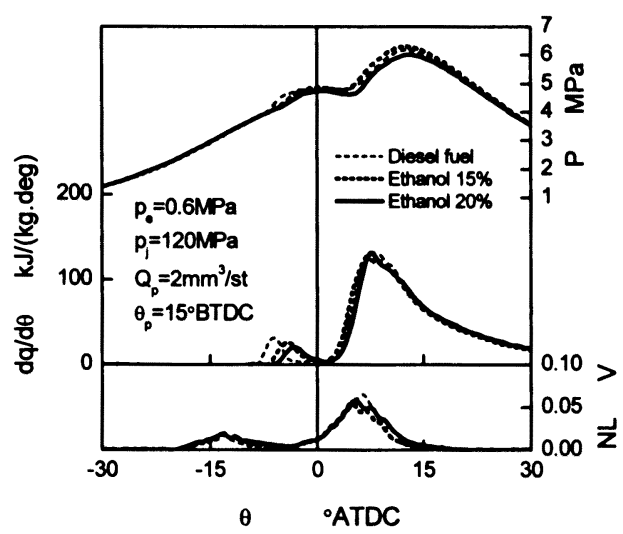

Fig. 7 Effects of ethanol blending ratio on combustion process

図 8 は正味熱効率 $\eta_{\mathrm{e}}$ および排出物啠の浱度に及ほ すエタノール混合割合の影䀤を示す. 混合割合の上 昇によって, Smoke, NOx およびCOの排出至が娍少 し, $\eta_{\mathrm{e}}$ が増加する. 前述のように筒内圧力の低下が 見られることから，然焼温度の低下により NOx が減 少し，さらに熱損失の低下により，熟効率が改善さ れたものと考えられる. なお，THC 排出彗度に及ほ すエタノール混合量の影策は小さい.

3·2.4 EGR とエタノール混合の組み合わせ NOx 排出湍度の大きな低減には, EGR が必須である. そ こで, EGR とエタノールの混合を組み合わせたとき の排気特性を調べた.

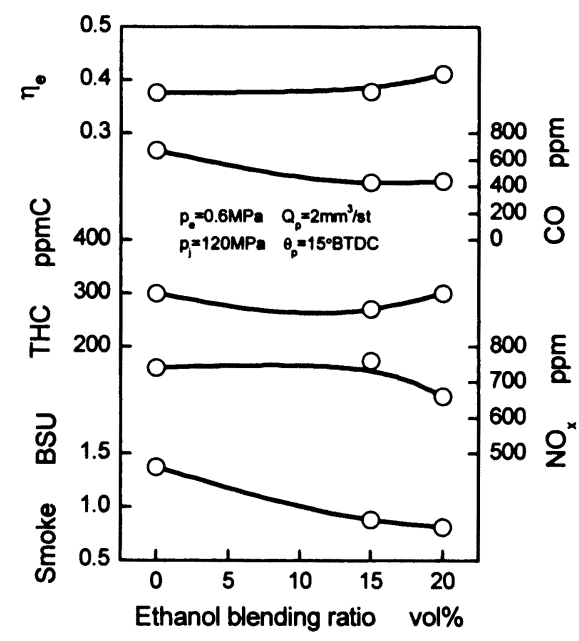

Fig. 8 Effects of ethanol blending ratio on emissions 


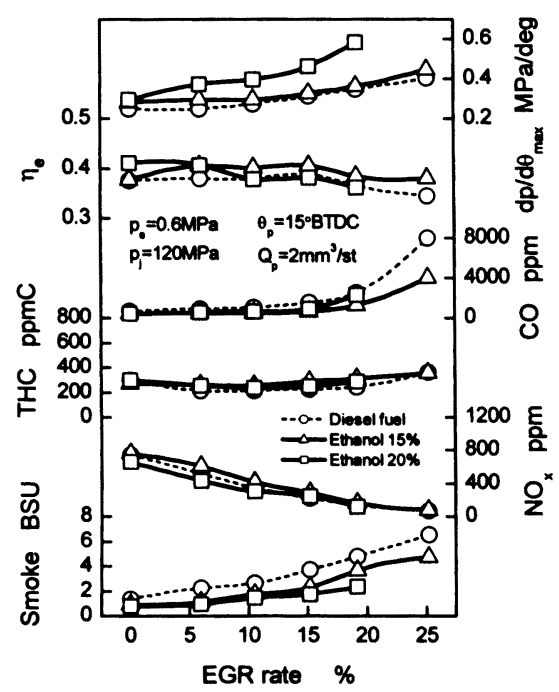

Fig. 9 Effects of EGR on emissions under various ethanol belnding ratios

図 9 はエタノール混合割合を $20 \%$ ば，EGR 率を 25\%まで変化させたときの排出物啠湍度，正味熱効率 $\eta_{\mathrm{c}}$ およひ最大圧力上昇率 $\mathrm{d} p / \mathrm{d} \theta_{\max }$ の変化を示す．なお, 混合割合を $20 \%$ としたときは, EGR 率を $25 \%$ まで上 昇させると然㛞変功が非常に大きくなり，出力を維 持した運転ができなかった．EGR 事の增加によって NOx 排出流度が大幅に娍少するが，燃料による差は 小さい. また, EGR 事の增加によってどの然料でも Smoke が增加するが, 高 EGR 率においてエタノール 混合然料では增加が小さく， EGR=20\%，エタノール 混合割合 $20 \%$ においては怪油に比べ大幅に低下する. しかし，混合割合が $20 \%$ 場合には, EGR 率の增加 にともなって $\mathrm{d} p / \mathrm{d} \theta_{\max }$ が急激に上㫒しており，これが 実用上問題になる.

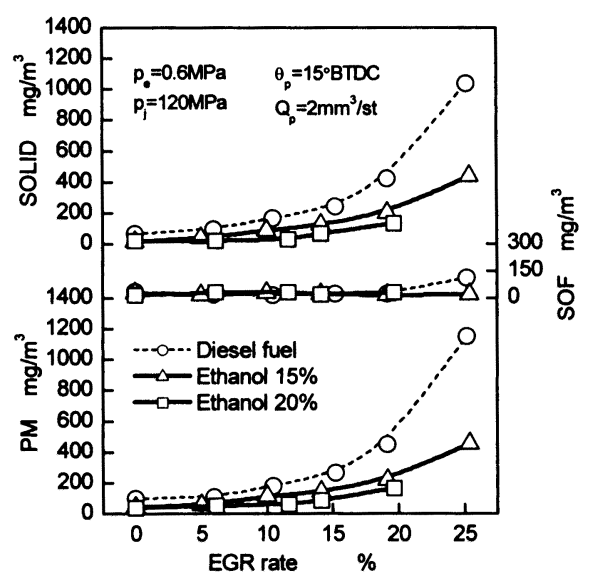

Fig. 11 Effects of EGR rate on PM emissions under various ethanol blending ratios

図 10 は同じ条件での筒内圧力 $p$, 熱発生率 $\mathrm{d} q / \mathrm{d} \theta$ を 示す. EGR 率 $20 \%$, エタノール混合割合 $20 \%$ の場合, EGR によってパイロット噴射の着火遅れが長くなり, 発生熱量も大きく減少するため, 主然料の初期熱発 生率が増加する.これが前述の $\mathrm{d} p / \mathrm{d} \theta_{\max }$ の增加につな がる. 他の然料の場合でも同様の傾向が見られるが, その変化は小さい。これは，エタノール混合量の増 加によって燃料の着火性は大きく悪化するためと考 えられる.この結果については, さらに検討する必 要がある.

図 11 は EGR に対する粒子状物質 PM, 可溶有機成 分 SOF および不溶性成分 Solid の排出浱度の変化を示 す. EGR 率が高くなるにつれて PM の排出浱度が増 加する. しかし, Smoke と同様に, エタノール混合 によって高 EGR 率においても PM 排出浱度の増加が 抑制され，EGR 率 20\%，エタノール混合割合 $20 \%$ に おいて柽油に比べて PM が 70\%减少する。また, PM

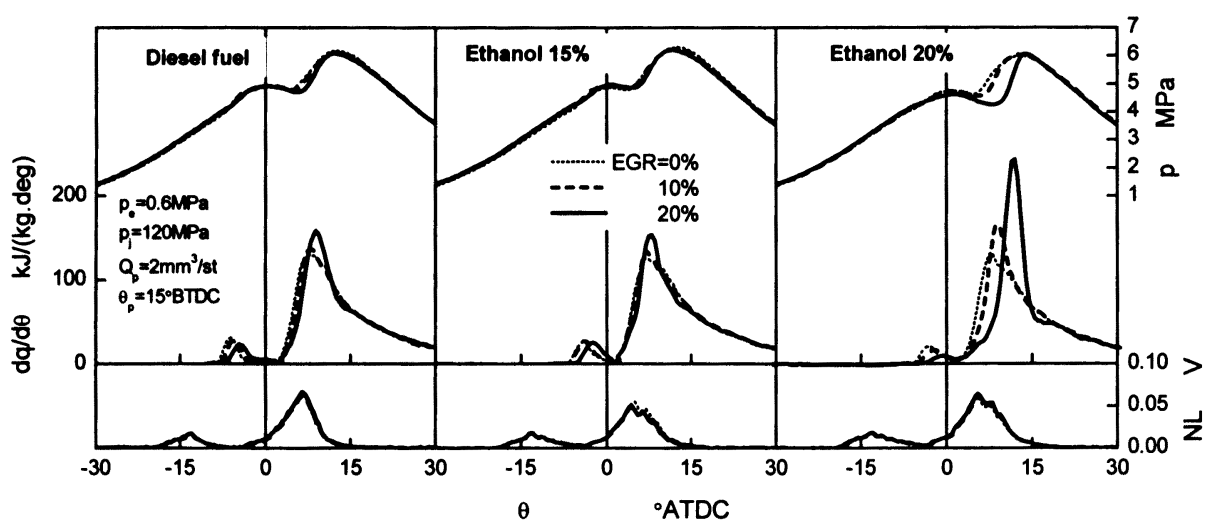

Fig. 10 Effects of ethanol blending ratio on combustion process under various EGR rates 


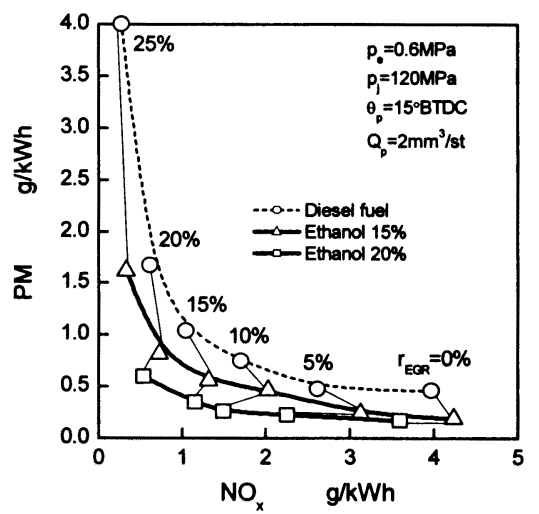

Fig. 12 Effects of EGR rate on NOx-PM trade-off のうち，特に Solid が抑制されていることがわかる.

図 12 は EGR 率を変更させたときの PM と NOx の 関係を示す．図よりエタノール混合により PM と NOx のトレードオフ関係が改善されることがわかる. エタノール 20\%然料では EGR 率 20\%を用いることに よって NOx 排出量 $0.52 \mathrm{~g} / \mathrm{kWh}$ に対して $60 \%$ 以上の PM 低減が得られる.

\section{$3 \cdot 3$ 低負荷における性能・排気の改言}

図 2 で指摘したように低負荷運転時に CO および THC の排出量增加の問題がある. これは, 長い着火 遅れにより燃焼限界を超える希薄混合気が形成され ることが原因と見られる．そこで，主としてパイロ ット噴射による改善を目指し，噴射条件の最適化に ついて検討した.

3·3・1 噴射圧力の影彎 まず，噴射圧力の上昇に

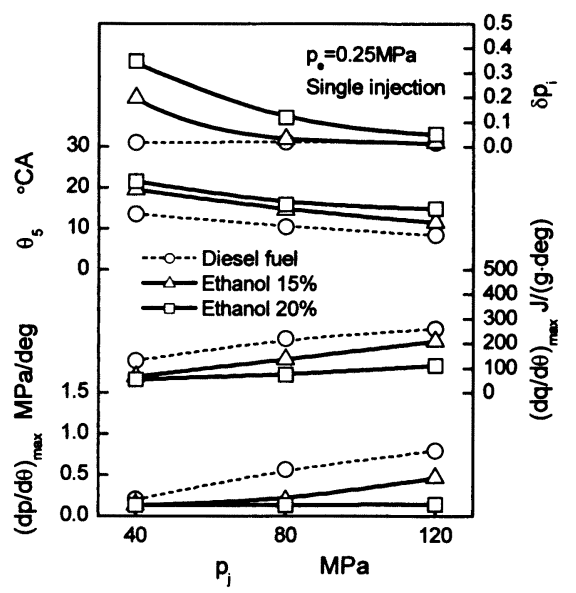

Fig. 13 Effects of injection pressure on combustion characteistics under a low engine load
よる着火遅れの短縮と性能・排気の改善効果を調べ た. 図 13 は正味平均有効圧力 $p_{\mathrm{e}}=0.25 \mathrm{MPa}$ のときの燃 焼特性に及ほす噴射圧力 $p_{\mathrm{j}}$ の影䇾を示す。ここで $\delta_{\mathrm{pi}}$ は燃焼変動の指標で，50 サイクルにおける図示平均 有効圧力の標準偏差を平均值で割り算して求めた.

噴射圧力が低いと，エタノール混合割合の増加によ って燃焼変助率 $\delta_{\mathrm{pi}}$ が大きく增加しているが，噴射圧 力の上昇によって着火遅れが短縮され， $\delta_{\mathrm{pi}}$ も低く抑 えられる.もし，許される最大の $\delta_{\mathrm{pi}}$ を 0.1 と考えると， エタノール $15 \%$ および $20 \%$ で利用可能な $p_{\mathrm{j}}$ はそれぞ れ $80 \mathrm{MPa}$ と $100 \mathrm{MPa}$ になる.この噴射圧力の籁囲で 排出物倎濃度ならびに正味熱効率 $\eta_{\mathrm{e}}$ をプロットして 図 14 に示す. 燃焼変動は抑えられたものの, $\mathrm{CO}$, THC の排出量はエタノール混合によって増加し，混

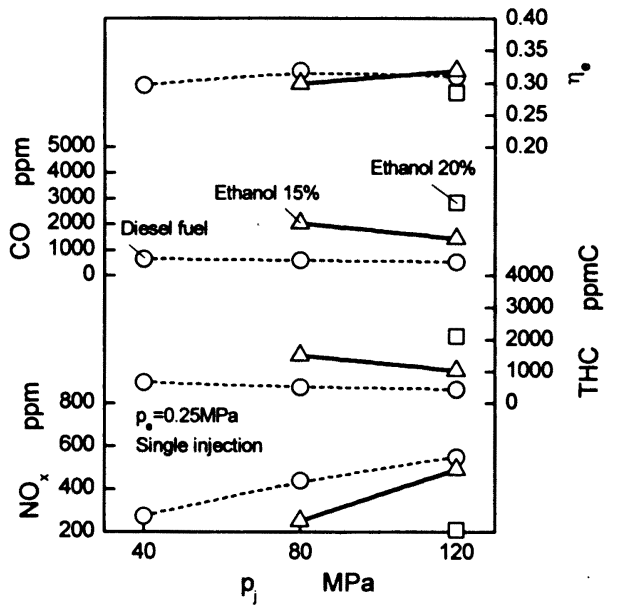

Fig. 14 Effects of injection pressure on emissions under a low engine load

合割合が増すほどに高い噴射圧力や噴射時期の早期 化を必要とするため, NOx の大幅な增加が避けられ ない.そこで次にパイロット噴射の適用を検討した 3.3.2 パイロット嘪射の適用図 15 は筒内圧力 $p$, 熱発生率 $\mathrm{d} q / \mathrm{d} \theta$ に及ぼすパイロット噴射の影䇾を 示す. 実験条件は $p_{\mathrm{e}}=0.25 \mathrm{MPa}, p_{\mathrm{j}}=80 \mathrm{MPa}, Q_{\mathrm{p}}=3 \mathrm{~mm}^{3} / \mathrm{st}$, $\theta_{\mathrm{p}}=20^{\circ} \mathrm{BTDC}$ である. 図より, どの燃料についてもパ イロット噴射を行うことによって大幅な着火遅れの 短縮が得られ，エタノール混合割合が多くなっても 主然料の熱発生開始を TDC 近くに配㩖できる.

次に，パイロット噴射量 $Q_{\mathrm{p}}$ が熱効率および排出物 質に及ぼす影敏について調べ，その結果を図 16 に示 す.エタノール混合燃料では，パイロット唄射によ って正味熱効率 $\eta_{\mathrm{e}}$ が上昇し，埾油を上回った。これ は，図 15 に見られるように，パイロット然料の発熱 


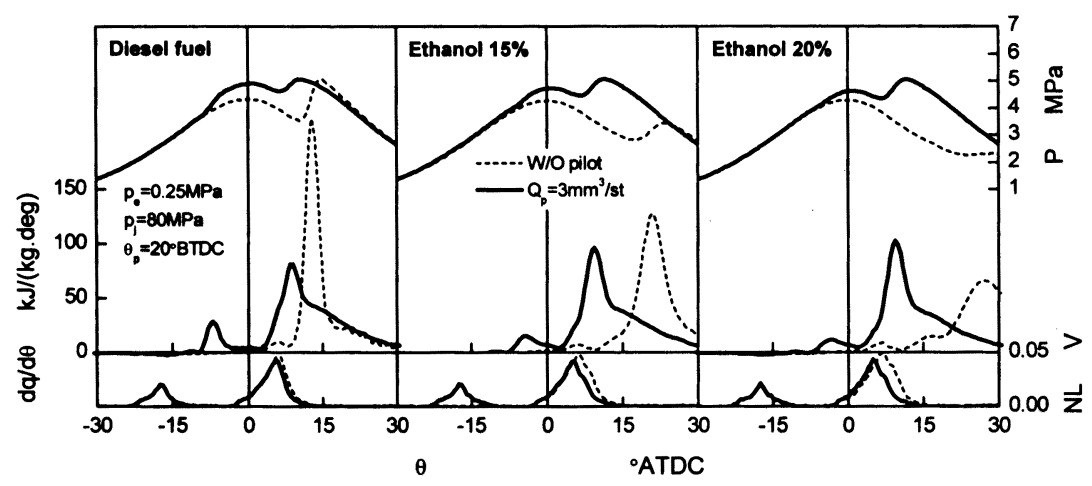

Fig. 15 Effects of pilot injection on combustion process under a low engine load

量が少なく, 上死点付近の温度上昇が小さいため, 㹩油に比べて冷却熟損失が低減されたためと推定さ れる、また，THCおよびCOの排出湍度はパイロッ 卜噴射によって大きく低下するが，パイロット噴射 量 $Q_{\mathrm{p}}$ の增加により徐々に增加する. 図より, 怪油の 場合， $Q_{\mathrm{p}}$ を 1 2 $\mathrm{mm}^{3} / \mathrm{st}$ に設定すれば NOx の增加を防 げる.エタノール混合然料の場合は，2 3 $\mathrm{mm}^{3} / \mathrm{st}$ とや やパイロット噴射量を多くすると比較的低いTHC, CO, NOx 湌度にできる.これは, エタノールは軽油 と比べて発生熱旦が少ないためと考えられる.

図 17 は炭化水素, アルデヒド等微量成分の裖度を， パイロット嗔射を行わないときと（w/o）， $Q_{\mathrm{p}}=3$ $\mathrm{mm}^{3} / \mathrm{st}$ としてパイロット噴射を行ったとき(w)とで比 較した結果を示すここで, LHC は低沸点炭化水素 $\left(\mathrm{CH}_{4}, \mathrm{C}_{2} \mathrm{H}_{4}, \mathrm{C}_{2} \mathrm{H}_{6}, \mathrm{C}_{3} \mathrm{H}_{6}, \mathrm{C}_{6} \mathrm{H}_{6}\right)$ の総湌度を示す. 図 より, パイロット噴射を行わない場合, エタノール 混合によって CO, THC, LHC, アルデヒド類

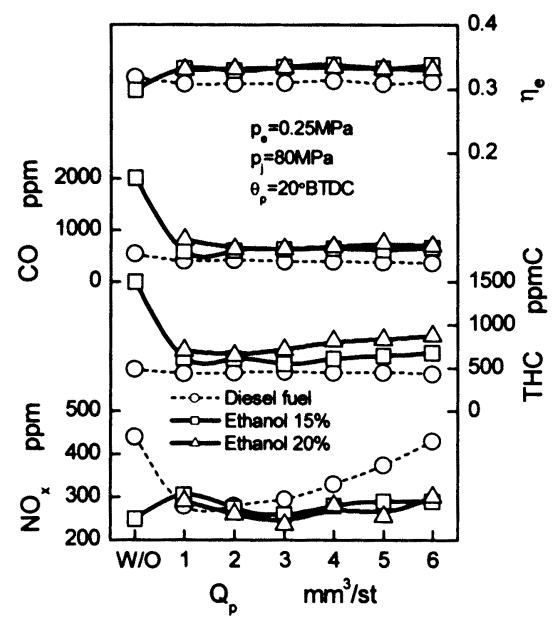

Fig. 16 Effects of pilot amount on emissions under a low engine load
$\left(\mathrm{HCHO}+\mathrm{CH}_{3} \mathrm{CHO}\right)$ やアルコール類 $\left(\mathrm{CH}_{3} \mathrm{OH}+\mathrm{C}_{2} \mathrm{H}_{5} \mathrm{OH}\right)$ の 排出漘度は軽油運転時と比べて大きく増加するが, パイロット噴射によってこれらの排出浱度が大幅に 減少する. ただし, アルコール類の排出丧度は減少 するものの, 軽油と同等まで减らすことはできない.

\section{4. おわりに}

パイロット噴射が可能な高圧燃料噴射装置および Cold-EGR を採用したディーゼル機関においてエタノ 一ル混合燃料が機関性能, 排気特性に与える影響に ていて検討を行った結果, 次のような知見が得られ た.

\section{高負荷運転時}

（1）エタノール混合燃料を用いた場合，噴射圧力の 上昇によって無煙燃焼が得られるが，高い噴射 圧力では軽油に対して黒煙低减のメリットは弱 まる。

(2) 最適なパイロット噴射によってエタノール混合 による燃焼騒音の増加を防ぐことができる.

(3) エタノール混合割合が上昇するとパイロット噴 射の着火および燃焼に多少の影響が見られるが 主然料の燃焼形態はあまり変わらない。Smoke, NOx および CO の排出湌度がエタノール混合割 合の上昇によって減少し, 熱効率が上昇する. ただし，エタノール割合を $25 \%$ まで上昇させ ると燃焼変動が激しくなり, 出力を一定に保つ ことが困難になる。

(4) エタノール混合, 高圧噴射, パイロット噴射と EGRの組み合わせによって PM の増加が小さく， NOx の低减が可能になり, NOx-PMトレードフ が改善できる.ただし，エタノール混合割合が 多いとき高い EGR 率を用いると, 圧力上昇率 が過大になる. 

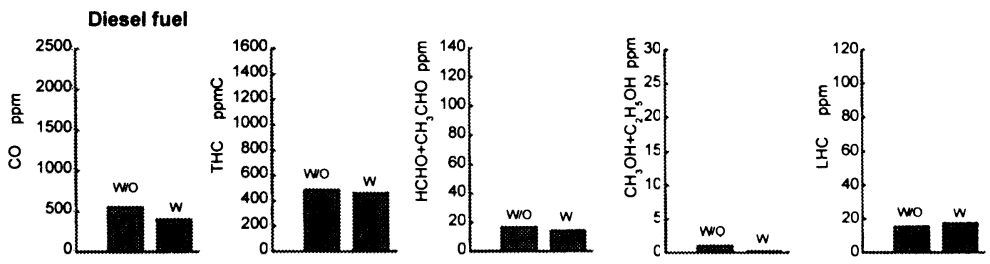

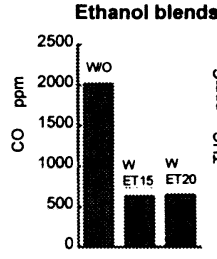

co

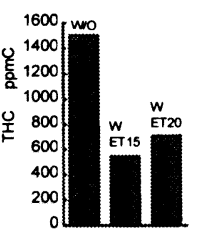

THC

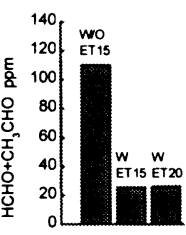

Aldehyde

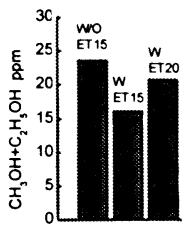

Alcohols

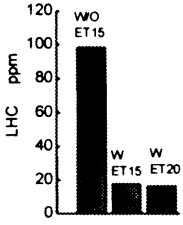

LHC

Fig. 17 Effects of pilot injection on unburned emissions under a low engine load

\section{低負荷運転時}

（5）低負荷運転時では噴射圧力の上昇により着火遅 れが短縮し，燃焼変動が小さくなる。このとき THC および COの排出が低减される。しかし， エタノール混合割合が多くなるほど然焼変動の 増加を回避するために高い噴射圧力が必要とな り, NOx の增加がさけられない.

(6) 最適なパイロット噴射は着火遅れの短縮に有効 で NOx を低く保ちながら THC，CO およびア ルデヒド類が低减できる。

終わりに, 実験に際し大学院生, 松本哲平氏に多 大なご協力を得たことに対して梁く感謝します。ま た，噴射系を提供いただいた(株)卜ヨ夕自動車に対し て御礼申し上げます，なお，本研究は京都大学 21 世 紀 COE プログラム「環境調和型エネルギーの研究教 育拠点形成」の助成を受けた。

\section{文 献}

(1) Murayama, T., et al., JSME Bull, 26(216), pp.10431049, (1983).

(2) Eugene, E.E., et al., SAE paper, 840118, (1984).

(3) MacLean, H.L., et al., J. Air Waste Manage. Assoc., 50(10), pp.1769-1779, (2000).

(4) McCormick, R.L. and Parish, R., NREL/MP-54032674, (2001)

(5) Hansen, C.A., et al., BioResourceTechnology, vol. 96, Issue 3, pp.277-285, (2005).
(6) Xing-Cai, L., et al., Fuel, 83, pp.2013-2020, (2004)

(7) Poulopoulos, S.G, et al., Atmospheric Environment, 35, pp.4399-4406, (2001).

(8) He, B.Q., et al., SAE Paper, 2003-01-0762, (2003).

(9) Cole, R.L., et al., SAE paper, 2001-01-1937, (2001).

(10) Czerwinski, J., SAE Paper, 940545, (1994).

(11) Miwa, K., et al., Proc. VIIIth Int. Symp. On Alcohol fuels, pp.595-600 (1988).

(12) lkegami, M., et al., SAE paper, 831290, (1983). 